\title{
THE EFFECTS OF ORGANIZATIONAL COMMUNICATION AND COMMITMENT ON ORGANIZATIONAL IDENTIFICATION: A SECTORAL COMPARISON
}

\author{
ALPER ERTÜRK* \\ Gebze Institute of Technology
}

\author{
NIGAR DEMIRCAN** \\ Gebze Institute of Technology
}

\author{
ADNAN CEYLAN*** \\ Gebze Institute of Technology
}

\begin{abstract}
This study examines the effects of organizational communication and commitment on organizational identification. We draw samples from organizations operating in service and manufacturing industries. In the analysis, career communication is found to be related significantly to organizational identification in the service industry, while task communication is related significantly to organizational identification in the manufacturing industry. The results also suggest that affective commitment, when combined with organizational communication and identification, fully mediates the relationship between organizational communication and employees' identification with the organization. This study has also some conclusions about the roles of organizational communication and commitment in fostering organizational identification.
\end{abstract}

Key words: organizational identification, task communication, career communication, organizational commitment.

\section{ÖRGÜTSEL ILLETIŞIMM VE BAĞLILIĞIN, ÖRGÜTSEL KIMMLIK ALGISI ÜZERINDEKI ETKILERI: SEKTÖREL BİR KARŞILAŞTIRMA}

ÖZET

Bu çalışma, örgütsel iletişim ve bă̆lllı̆̆ın örgütsel kimlik alglsı üzerindeki etkilerini incelemektedir. Hizmet ve imalat endüstrisinde faaliyet gösteren firmalar örnekleme dahil edilmiştir. Yapılan analiz neticesinde, imalat endüstrisinde görev iletişimi örgütsel kimlik alglsl üzerinde anlamlı etkiye sahipken, hizmet endüstrisinde kariyer iletişiminin örgütsel kimlik algısı üzerinde anlamlı etkisinin olduğu bulunmuştur. Bunların yanında sonuçlar, örgütsel iletişim ve kimlik alglsı ile birlikte ele

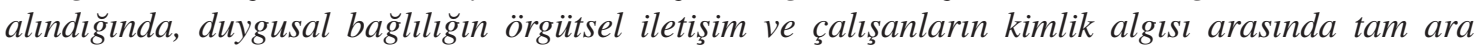
değissken etkisi yarattı̆̆ını göstermiştir. Bu çalışmada ayrıca, örgütsel iletişim ve bağlılı̆̆ın örgütsel kimlik algısını artırıcı yöndeki etkileri de tartışılmıştır.

Anahtar kelimeler: örgütsel kimlik algısı, görev iletişimi, kariyer iletişimi, örgütsel bă̆lllık.

\footnotetext{
* Alper Ertürk is an instuctor in the Faculty of Management at the Gebze Institute of Technology, Çayırovca Fabrika Yolu, No. 101, 41400, Gebze, Kocaeli, Turkey. E-mail: (yeldaalper@yahoo.com)

** Nigar Demircan is an Associate Professor in the Faculty of Management at the Gebze Institute of Technology, Çayırovca Fabrika Yolu, No. 101, 41400, Gebze, Kocaeli, Turkey. E-mail: (ndemircan@gyte.edu.tr)

*** Adnan Ceylan is an Associate Professor in the Faculty of Management at the Gebze Institute of Technology, Çayırovca Fabrika Yolu, No. 101, 41400, Gebze, Kocaeli, Turkey. E-mail: (ceylan@ gyte.edu.tr)
} 
As information technology facilitates the globalization of organizations, management is faced with the responsibility of adapting to a rapidly changing environment filled with uncertainty and anxiety. "In response to the anxiety of the present, organizations have increasingly turned to control systems that demand high levels of worker identification" (Barker and Tompkins, 1994: 239). Employees who identify strongly with their organizations are more likely to show a supportive attitude toward them (Ashforth and Mael, 1989). Therefore, organizations should engender identification to facilitate their functioning (Cheney, 1983; Pratt, 1998).

The concept of organizational identification has been studied by researchers in the area of organizational behavior and defined as "the degree to which a member defines him/herself by the same attributes that he or she believes define the organization" (Dutton et al., 1994). Identification is said to result in an organizational identity for the individual that is part of his/her social identity (Ashforth and Mael, 1989).

Research regarding the effects of communication on the individual's attitudes toward the organization (e.g. Huff et al., 1989; Sproull and Kiesler, 1986) provides a theoretical link between organizational communication and organizational identification. Specifically research has found that communication can affect employee attitudes that may be strongly related to organizational identification (Wiesenfeld et al., 1999). And also it often has been observed that communication creates the conditions for commitment and hence should be seen as one of its important antecedents (Foy, 1994; Katz and Kahn, 1972; Meyer and Allen, 1997; Postmes et al., 2001).

These studies have suggested that organizational identification influences and is influenced by a variety of organizational processes and perceptions. Accordingly, the purpose of this study is to investigate the impact of organizational communication and commitment on employee identification. We also propose that organizational commitment will mediate the relationship between organizational communication and organizational identification. We further investigate the effects of organizational communication on employee identification.

\section{LITERATURE REVIEW ON ORGANIZATIONAL IDENTIFICATION}

Organizational identity, defined as members' shared beliefs about the organization's central, enduring and distinctive characteristics (Albert and Whetten, 1985; Ashforth and Mael, 1989; Dutton and Dukerich, 1991), was suggested as a critical factor holding organizations together (Wiesenfeld et al., 1999). Furthermore, by defining the organization, an organization's identity guides members' feelings, beliefs and behaviors (Dutton and Dukerich, 1991). Therefore, identification represents the social and psychological binding between employees and the organization (Wiesenfeld et al., 1999).

Organizational identification concerns the perception of "oneness" with an organization (Ashforth and Mael, 1989). The construct has firm roots in social identity theory. From social identity theory, two basic motives for identification can be defined (Pratt, 1998). The first is the need for selfcategorization (Turner, 1987), which may help to define "the individual's place in society" (Tajfel, 
1981: 255). The second is the need for self-enhancement, which requires that group membership be rewarding (Smidts et al., 2001).

There is a general agreement that organizational identification is accompanied by cognitive, affective and behavioral components (Cheney and Tompkins, 1987; Harquail, 1998). The more the member comes to view the organization as definite of his or her own self, the stronger the identification and the higher the cognitive, emotional and behavioral investment of the individual in the organization (Chreim, 2002). The cognitive component of identification reflects the perceived amount of interests on the individual and on organization share (Ashforth and Mael, 1989). It conveys the extent to which an individual perceives him/herself as being a typical member of it. The affective component, that is feeling of pride in being part of the organization or feeling acknowledged in it, is important in the creation of a positive image of one's own organization or in achieving a positive social identity (Tajfel, 1978; Smidts et al., 2001).

Research suggests that strength of identification determines some critical beliefs and behaviors. Among them are employees' feelings of interpersonal trust, goal-setting processes, the internalization of organizational norms and practices, the desire to remain with the organization and willingness to cooperate with others (e.g. Dutton et al., 1994; Wiesenfeld et al., 1999). Similarly, member identification satisfies a number of individual needs, including the needs for safety, affiliation, selfenhancement and meaning in one's life (Pratt, 1998).

Organizational identification, which provides a psychological link between workers and the organization, facilitates coordination because it leads to convergent expectations (Wiesenfeld et al., 1999). Identification motivates members to coordinate their efforts to achieve organizational goals by enhancing interpersonal trust and cooperation (Brewer, 1981; Kramer and Brewer, 1984 and 1986). Additionally, research suggests that members who identify strongly with the organization are more likely to accept organizational goals as their own personal goals and are more likely to be loyal and obedient (Dutton et al., 1994). Similarly, organizational identification is expected to correlate with work effort, willingness to perform extra-role behaviors and task performance (Dutton et al., 1994).

Extant research has linked organizational identification to a wide variety of organizational phenomena and behaviors including organizational house organs (e.g. Cheney, 1983), organizational commitment (e.g. Siegel and Sisaye, 1997), decision-making premises (e.g. Bullis and Tompkins, 1989), organizational socialization (e.g. Bullis and Bach, 1989), self-managing teams (e.g. Barker and Tompkins, 1994), supervisor communication (e.g. Myers and Kassing, 1998; Scott, 2002), organizational justice (e.g. Brewer and Kramer, 1986), wearing organizational uniforms (e.g. Pratt and Rafaeli, 1997), charismatic leadership (e.g. Kets de Vries, 1988; Lindholm, 1988), transformational leadership (e.g. Ashforth and Mael, 1989), organizational trust (e.g. Roueche and Roueche, 1996), cooperation (e.g. Polzer, 2002), organizational citizenship behaviors (e.g. Wiesenfeld et al. 1999), organizational culture (e.g. Schrodt, 2002), job satisfaction and turnover (e.g. Van Knippenberg and Van Schie, 2000; Fontenot and Scott, 2000; Scott, 2002), employee participation (e.g. Van Knippenberg and Van Schie, 2000) and control in the workplace (e.g. Barker and Tompkins, 1994). 


\section{MODEL DEVELOPMENT}

\section{The Relationship between Organizational Communication and Organizational Identification}

Frank and Brownell (1989:5-6) define organizational communication as "the communication transactions between individuals and/or groups at various levels and in different areas of specialization that are intended to design and redesign organizations, to implement designs and to coordinate day-to-day activities." Communication is a multi-dimensional construct (Smidts et al., 2001). Hence, employees are not satisfied or dissatisfied with communication in general, but can express varying degrees of satisfaction about definite aspects of communication (Smidts et al., 2001; Clampitt and Downs, 1993).

In the organizational communication literature, organizational identification is defined as a languagebased process of sharing in the substance of an organization (Sass and Canary, 1991; Chreim, 2002). In this literature, identification is seen as the result of different factors, the most significant of which is communication by management (vertical communication), which is considered an important component in inducing member identification with the organization (DiSanza and Bullis, 1999). Furthermore, the concept of vertical communication is believed to have a greater impact on identification and commitment, because vertical communication should help define what the organization stands for (Postmes et al., 2001). By enhancing the distinctiveness, vertical communication would thereby make it easier for people to identify themselves with the organization as an entity (Ashforth and Mael, 1989; Postmes et al., 2001).

Communication helps create shared meaning because it provides social context cues (Sproull and Kiesler, 1991), and creates a shared interpretive context among organization members (e.g. Zack, 1993). Shared meaning provides organization members with a clear sense of the organization's identity and thus may strengthen member identification. Pfeffer (1981) suggests that frequent communication by management leads to the development of a common set of shared meanings about the organization that provides members with a sense of belongingness and identity.

Whereas social categorization would require that employees receive adequate information about what is central and distinctive about their organizations, self-categorization (Turner, 1987) can be facilitated when employees are provided with useful information about their roles, duties, in organizations (Smidts et al., 2001), their performance and their career. Thus, being well-informed about organizational goals, objectives, activities and achievements will enable an organization's members to discover the salient characteristics that distinguish this organization from others (Dutton et al., 1994) and thus enhance social-categorization (Smidts et al., 2001). In organizations that are perceived favorably by their members, organizational identification is more likely to occur (Dutton et al., 1994), since it enhances members' feelings of self-worth. Similarly, Smidts et al. (2001) demonstrated that both communication content and climate affected organizational identification in a positive way. According to them, communication climate also plays a central role, mediating the impact of the content of communication on organizational identification (Smidts et al., 2001).

Accordingly, we propose that communication can strengthen member identification because it provides organization members with an opportunity to create and share their subjective perceptions of the organization's defining features - its norms, values and culture. Knowledge of these facets of the organization creates a sense of shared meaning among employees. 
Therefore, we hypothesize that,

H1: Organizational communication strengthens employee's organizational identification.

\section{The Effect of Organizational Communication on Organizational Commitment}

Organizational communication strengthens employees' commitment by providing workers with a feeling of ownership in the shared meaning that has been created, because they feel that they have helped develop it (Wiesenfeld et al., 1999). Similarly research suggests that frequency with which individuals communicate with others in the organization enhances organizational commitment because frequent communication leads individuals to feel that they are active participants in the organization (Huff et al., 1989). Besides Postmes et al., (2000) found that organizational communication and organizational commitment are related to each other positively. In particular, employees were strongly committed if they obtained adequate information to perform their task (task communication), and if this information was presented to them via formal bureaucratic channels rather than informally.

Similarly, research has suggested that vertical communication (communication with management) is a stronger predictor of organizational commitment, while horizontal communication (communication with colleagues) is related weakly to organizational commitment (Postmes et al., 2000). Organizational communication may have its impact on organizational commitment primarily because it reduces uncertainty and thereby helps employees define and comprehend what their organization is about. Therefore, vertical communication may aid in the self-definition of an organization and thereby reinforce employees'self-definition within it (Postmes et al., 2001).

With respect to information about personal roles in an organization, employees receiving useful and sufficient information about what is expected of them in their work (task communication) and regarding their contributions (performance communication) will increase their understanding of the norms and values of respected membership (Smidts et al., 2001). Also, receiving sufficient information about future opportunities and career advice (career communication) will encourage development, adaptation (Penley and Hawkins, 1985) and employee's self-enhancement. Such information not only will provide basis for self-categorization, but also will enhance members' sense of belonging to, involvement with and commitment to the organization (Lawler, 1989) and will increase their self-enhancement.

Hence, we hypothesize that,

H2: Organizational communication strengthens employee's organizational commitment.

\section{Organizational Identification versus Organizational Commitment}

Several authors have argued that there are important differences between commitment and identification (e.g. Mael and Tetrick, 1992; Pratt, 1998; Van Knippenberg and Sleebos, 2000). Others have questioned the distinction between the two conceptually (Miller et al., 2000). On the basis of Tajfel's (1972) original definition of social identity, it recently has been proposed that commitment should be considered as one of three components of social identification (Ellemers et al., 1999). Conversely, the work of Meyer and Allen (1991) has suggested that the affective component of employees' commitment refers to the employes' emotional attachment to identification with and 
involvement in the organization (Meyer and Allen, 1991, 1997). Also, research has yielded that organizational identification strengthens employees' organizational commitment (Siegel and Sisaye, 1997; Sass and Canary, 1991; Roueche and Roueche, 1996; Cheney and Tompkins, 1987).

Although, organizational identification and organizational commitment are seen as almost identical notions in the literature, research suggests that organizational identification is different from and stronger than organizational commitment (Mael and Tetrick, 1992; Mael and Ashforth, 1995; Siegel and Sisaye, 1997). Identification is a perceptual cognitive construct reflecting the overlap in individual and group identities that is distinct from behavior and affect (e.g. satisfaction, loyalty and commitment) (Iyer, Bamber and Barefield, 1997). Research also shows that organizational identification can be distinguished from other related constructs, such as commitment (e.g. Caldwell, Chatman and O'Reilly, 1990; Mael and Ashforth, 1992).

Thus, we hypothesize that,

H3: Organizational commitment strengthens employees' identification, mediating the effects of organizational communication on identification.

\section{METHOD}

\section{Sample and Procedure}

First, each questionnaire was translated from English into Turkish with the assistance of official translators, and then back-translated into English. Then, we administered the questionnaires to randomly selected 10 employees for a pilot survey. During the pilot survey, the questions were proved to be easily understood by employees, who generally gave full responses.

In order to investigate empirically the hypothesis, the data were collected from four companies in the service and manufacturing industries. Each questionnaire was accompanied by a cover letter to assure confidentiality. Moreover, respondents were asked to return the completed questionnaires directly to our assistant to ensure their anonymity. From 400 questionnaires distributed, 133 completed questionnaires were returned with a response rate of $33 \%$. After deleting records with missing cases, 121 questionnaires remained and constituted the sample for this study. Of those 121 questionnaires, 41 were from the service industry and 80 were from the manufacturing industry.

Some demographic data were collected, such as age, gender, tenure in the organization and education level. No personal data were collected except demographics. The average respondent was 32 years old (standard deviation of 9.28) and ages ranged from 18 to 55 years. The sample was $72.7 \%$ male and $63.6 \%$ of the respondents were married. Survey respondents had worked for their organizations for an average of 9.65 years (standard deviation of 8.73) and a range from 1 month to 29 years. Eighty-four percent of the respondents were at least high school graduates. 


\section{Measures}

In this study, we measured two dimensions of organizational communication, career communication and task communication, with scales developed and tested by Penley and Hawkins (1985).

Career communication scale included five items that measured the extent to which supervisors discussed training opportunities with subordinates and provided them with career advice (e.g. "My supervisor discusses with me how to get additional training"). The alpha reliability of this scale was 0.89 .

Task communication measure included four items that measured the extent to which supervisors let subordinates know what needed to be done, explained changes in the workplace and explained the policy (e.g. "My supervisor lets us know about changes that are coming up"). The alpha reliability of this measure was 0.95 .

Organizational identification was measured with five items (e.g. "When someone praises my organization, it feels like a personal compliment.") developed by Mael and Ashforth (1992). The alpha reliability of this scale was 0.87 .

Organizational commitment was assessed with seven items from Meyer and Allen's (1991) affective commitment scale (e.g. "I would be happy to work at my organization until I retire") with an alpha reliability of 0.82 .

All items were measured on a five point Likert-type scale where one indicates "strongly disagree" and five indicates "strongly agree." Scale items are presented in Appendix A.

\section{Factor Analysis and Reliabilities}

Since the scales were used with a new sample, the scales were submitted to exploratory factor analysis separately. The best fit of the data was obtained with a principal factor analysis with a varimax rotation.

Table 1

Factor Loadings of Organizational Communication Items

\begin{tabular}{ccc}
\hline Item & $\begin{array}{c}\text { Factor 1 } \\
\text { Career } \\
\text { Communication }\end{array}$ & $\begin{array}{c}\text { Factor 2 } \\
\text { Communication }\end{array}$ \\
\hline 1 & 0.808 & \\
2 & 0.780 & \\
3 & 0.934 & \\
4 & 0.654 & 0.929 \\
5 & & 0.798 \\
6 & & 0.971 \\
7 & & 0.963 \\
8 & & 0.682 \\
9 & & \\
\hline
\end{tabular}


The exploratory factor analysis for organizational communication revealed a two-factor structure as expected. Five items loading on the first factor reflected "career communication" and the second factor including four items reflected "task communication." The factor loadings for organizational communication items are displayed in Table 1.

After the exploratory factor analysis, a five-item organizational identification measure produced a one-factor solution allowing the retention of all five of its original items.

The obtained factor structure for organizational commitment was found to be a single factor with six items after the elimination of one poor performing item.

We calculated means and standard deviations for each variable and created a correlation matrix of all variables used in hypothesis testing. The means and standard deviations are within the expected ranges.

We used the Cronbach's alpha to estimate reliability for scales. The scales met the generally accepted reliability of 0.70 (Nunnally, 1978). Means, standard deviations, reliabilities, and correlations among all scales used in the analyses are shown in Table 2.

Table 2

Descriptive Statistics, Reliabilities and Correlations

\begin{tabular}{lllllll}
\hline Variables & Mean & S.D. & $\mathbf{1}$ & $\mathbf{2}$ & $\mathbf{3}$ & $\mathbf{4}$ \\
\hline 1. $\quad$ Career communication & 3.21 & 1.090 & $0.95^{\mathrm{a}}$ & & \\
2. $\quad$ Task communication & 3.56 & 0.89 & $0.759^{* *}$ & 0.89 a & \\
3. Organizational identification & 4.10 & 0.71 & $0.406^{* *}$ & $0.375^{* *}$ & 0.87 a \\
4. Organizational commitment & 3.51 & 0.83 & $0.530^{* *}$ & $0.476^{* *}$ & $0.639^{* *} 0.82$ a \\
\hline ** Correlation is significant at 0.01 & & & & & \\
a Cronbach's alpha
\end{tabular}

RESULTS

We tested the hypotheses with multiple regression analyses (Cohen and Cohen, 1983) that enable the comparison of service and manufacturing sectors. First, career and task communication items were included as independents and their comparative impact on organizational identification (H1) examined. Second, the relative impact of combination of organizational measures on organizational commitment was investigated (H2). Third, organizational identification was added to independents for mediation tests $(\mathrm{H} 3)$.

Therefore the relationship between organizational communication and organizational identification was tested in a multiple regression model that included both measures of organizational communication (Table 3) and the models for both the service and the manufacturing sectors were found statistically significant $(\mathrm{Fs}=3.413, \mathrm{p}<0.05 ; \mathrm{Fm}=13.656, \mathrm{p}<0.01)$. In $\mathrm{H} 1$ we predicted that 
higher scores on a measure of organizational communication would be related to stronger identification to the organization. In support of the hypothesis, career communication is significantly related to organizational identification in service sector organizations $(b=0.423, p<0.05)$ whereas task communication $(b=0.347, p<0.01$ ) is significantly related to organizational identification in manufacturing organizations. That is, employees in service organizations are more concerned with the career guidance that their supervisors provide. However, employees in manufacturing organizations are concerned with clear explanations about changes and tasks about their work. Thus higher career communication in the service sector and task communication in the manufacturing sector lead to stronger employee identification.

Table 3

First Regression Model

\begin{tabular}{|c|c|c|c|c|}
\hline \multirow[b]{3}{*}{ Independents } & \multicolumn{4}{|c|}{ Organizational Identification } \\
\hline & \multicolumn{2}{|c|}{ Service Sector } & \multicolumn{2}{|c|}{$\begin{array}{l}\text { Manufacturing } \\
\text { Sector }\end{array}$} \\
\hline & $\beta$ & $\mathrm{T}$ & $\beta$ & $\mathrm{T}$ \\
\hline Career communication & 0.423 & $1.929 *$ & 0.186 & 1.196 \\
\hline Task communication & -0.138 & -0.629 & 0.347 & $2.228 * *$ \\
\hline $\mathrm{F}$ & \multicolumn{2}{|c|}{$3.413 *$} & \multicolumn{2}{|c|}{$13.656^{* *}$} \\
\hline $\mathrm{R}^{2}$ & \multicolumn{2}{|c|}{0.185} & \multicolumn{2}{|c|}{0.256} \\
\hline Adjusted $\mathrm{R}^{2}$ & \multicolumn{2}{|c|}{0.124} & \multicolumn{2}{|c|}{0.237} \\
\hline
\end{tabular}

** Correlation is significant at 0.01

* Correlation is significant at 0.05

H2 examined the relationship between organizational communication and organizational commitment and predicted that higher scores on a measure of organizational communication would be related to stronger organizational commitment. This hypothesis received statistically significant support in the service $(\mathrm{Fs}=6.370, \mathrm{p}<0.01)$ and also in the manufacturing $(\mathrm{Fm}=23.227, \mathrm{p}<0.01)$ sector. Accordingly, regression results indicate that career communication is positively related to employee commitment in both sectors, but the task communication was significant only in the manufacturing sector (Table 4).

Table 4

Second Regression Model

\begin{tabular}{lcccc}
\hline & \multicolumn{2}{c}{ Organizational Identification } \\
\cline { 2 - 5 } & \multicolumn{2}{c}{ Service Sector } & \multicolumn{2}{c}{$\begin{array}{c}\text { Manufacturing } \\
\text { Sector }\end{array}$} \\
\hline Independents & $B$ & $\mathrm{~T}$ & $\mathrm{~B}$ & $\mathrm{~T}$ \\
\hline Career communication & 0.560 & $2.782^{*}$ & 0.254 & 1.776 \\
Task communication & -0.80 & -0.40 & 0.389 & $2.716^{* *}$ \\
$\mathrm{~F}$ & & $6.370^{*}$ & \multicolumn{2}{c}{$23.227^{* *}$} \\
$\mathrm{R}^{2}$ & & 0.256 & \multicolumn{2}{c}{0.370} \\
Adjusted $\mathrm{R}^{2}$ & & 0.216 & \multicolumn{2}{c}{0.354} \\
\hline
\end{tabular}

** Correlation is significant at 0.01

* Correlation is significant at 0.05 
We also hypothesized in $\mathrm{H} 3$ that organizational commitment would effect organizational identification and we further proposed the proposition that organizational commitment would mediate the relationship between organizational communication and organizational identification. We tested this assumption with mediation analysis (Baron and Kenny, 1986). According to Baron and Kenny (1986), a mediator exists if (1) variations in the independent variable (career and task communication) account for significant variation in the mediator (organizational commitment), (2) variations in the mediator (organizational commitment) account for significant variations in the dependent variable (organizational identification), and (3) a previously significant relationship between the independent variable (organizational communication) and the dependent variable (organizational identification) is reduced or disappears when the mediator is included in the model.

Since the effects of independent variables (measure of organizational communication) and mediator on the dependent variable (organizational identification) already were examined (see Tables 3 and 4), we include organizational communication and commitment measures as independents to see the mediating effect of organizational commitment on the communication-identification relationship. If organizational commitment mediates the relationship, the significant effects of organizational communication dimensions on organizational identification should disappear or be reduced when organizational commitment is added to the model. This analysis is shown in Table 5.

Table 5

Third Regression Model

\begin{tabular}{lcccc}
\hline & \multicolumn{2}{c}{ Organizational Identification } \\
\cline { 2 - 5 } & \multicolumn{2}{c}{ Service Sector } & \multicolumn{2}{c}{$\begin{array}{l}\text { Manufacturing } \\
\text { Sector }\end{array}$} \\
\hline Independents & \multicolumn{2}{c}{$\mathrm{T}$} & \multicolumn{2}{c}{$\mathrm{T}$} \\
\hline Career communication & -0.004 & -0.025 & 0.055 & 0.488 \\
Task communication & -0.077 & -0.481 & 0.054 & 0.497 \\
Organizational commitment & 0.497 & $5.889^{* *}$ & 0.496 & $7.016^{* *}$ \\
F & \multicolumn{2}{c}{$14.634^{*}$} & \multicolumn{2}{c}{$28.305^{* *}$} \\
$\mathrm{R}^{2}$ & \multicolumn{2}{c}{0.549} & \multicolumn{2}{c}{0.416} \\
Adjusted $\mathrm{R}^{2}$ & \multicolumn{2}{c}{0.512} & \multicolumn{2}{c}{0.402} \\
\hline
\end{tabular}

** Correlation is significant at 0.01

* Correlation is significant at 0.05

When organizational commitment is added to the equation, both regression models were found to be statistically significant $(\mathrm{p}<0.01)$. The regression results indicate that organizational commitment is strongly and positively related to organizational identification. Additionally, the strength of career communication in the service sector and task communication in the manufacturing sector are disappeared $(p>0.1)$. Therefore, both in service and manufacturing organizations, the relationship between organizational communication and organizational identification is fully mediated by organizational commitment. Thus, the results indicate statistical support for the mediation of organizational identification. 


\section{DISCUSSION AND CONCLUSION}

In this study, we focused on the roles of organizational communication and commitment in fostering organizational identification. A main contribution of this study is that a meaningful relationship exists between organizational communication and employees' identification with the organization. An effect of organizational communication was indeed found, which confirmed the results of previous research that considered organizational communication as an important component in inducing employee identification with the organization (Sass and Canary, 1991; DiSanza and Bullis, 1999; Wiesenfeld et al., 1999; Postmes et al., 2000, 2001; Smidts et al., 2001; Scott, 2002; Chreim, 2002).

Career communication is found to be related significantly to organizational identification in the service industry. That is, employees in service organizations are more concerned with career guidance, which their supervisors provide. A clear and practical career suggestion and information for the employees provide a broader perspective about what kind of opportunities lay in their future. This guidance motivates employees to work harder in order to achieve their career goals. Also, this guidance helps employees understand the goals and vision of their organization. It is clear that communication between supervisors and employees that focuses on career opportunities encourages employees' adaptation and development (Penley and Hawkins, 1985). Furthermore, since their jobs are based on knowledge and interaction with people, employees in the service industry are more likely focused on their future careers. Hence, the kind of information that flows from supervisors to employees regarding careers would increase employees' identification through career communication in service organizations.

Task communication is found to be related significantly to organizational identification in the manufacturing industry. That is, employees in manufacturing organizations are more concerned with clear explanations about tasks and policies related to their work. Employees working in the manufacturing industry are doing more technical jobs in hard conditions and need more clarity in their tasks, job definitions and work policies. Task communication provides employees with the information regarding work standards, organizational rules and policies, working conditions and problems. This information helps them become more familiar with the organization and the work environment. Moreover, it helps employees define what the organization stands for and creates a shared context within the organization. Hence, task communication would increase employees' identification in manufacturing organizations.

In addition, career communication, such as taking the time to explain career opportunities, giving advice on developing the profession and discussing how to obtain additional training, is a characteristic of showing consideration. Similarly, task communication, such as explaining policy changes, letting people know what work needed to be done, and discussing work-related problems with subordinates, is a characteristic of showing consideration as well (Penley and Hawkins, 1985). In this manner, showing consideration through career and task communication will affect subordinates' commitment and identification with the organization positively by reducing uncertainty and helping create shared meaning.

Communication is a powerful catalyst for establishing and sustaining organizational identification, the emotional state that is shared by highly committed employees and managers. Thus, the results suggest that managers may strengthen organizational identification among employees who may not 
be intrinsically motivated to identify with the organization, by increasing communication between supervisors and subordinates. If employee identification affects business performance, fluent organizational communication can contribute significantly to the long-term success of an organization. Managers should therefore pay serious attention to internal communication between managers and employees by providing each employee with adequate information about the tasks and policy of organization and the opportunities to speak out, get involved, be listened to and actively participate. Good management, at least according to our findings and within these organizations, keeps employees well informed about the future directions of the organization (e.g. the organization's strategies and policies), allows them to interact with management about these policies, and allows this interaction to have impact on managerial decisions. In this sense, we can suggest that our findings are also consistent with the human relations perspective on organizations, which suggests that organizational communication is most productive in the sense of eliciting organizational commitment and identification (Postmes et al., 2001).

Third, although previous reseach suggestions (e.g. Wiesenfeld et al., 1999; Scott, 2002; Chreim, 2002) concerning the direct relationship between organizational communication and organizational identification were supported, this study reveals that the affective component of organizational commitment is more centrally linked to organizational identification than organizational communication.

The results also suggest that affective commitment, when combined with organizational communication and identification, fully mediates the relationship between organizational communication and employees' identification. This result is consistent with some previous research (Siegel and Sisaye, 1997; Ellemers et al., 1999). For instance, in their study regarding the relationship between organizational commitment and identification, Siegel and Sisaye (1997) alternatively suggest that the organizational commitment mediates the relationship between self-image congruance and organizational identification. Several studies have supported that those employees who show a high level of organizational commitment have positive attitudes about their employers and are more likely to identify closely with the goals of the organization by maintaining their loyalty and membership (e.g. Blau and Boal, 1987; Siegel and Sisaye, 1997).

As a conclusion, this study expands our understanding of organizational identification theory and it supports the previous research linking organizational identification with organizational communication (Smidts et al., 2001; Scott, 2002; Chreim, 2002) and organizational commitment (Siegel and Sisaye, 1997; Fontenot and Scott, 2000; Ellemers et al., 1999). Based on the results of this research, we conclude that there is a substantial relation between organizational identification and communication. However, this relation between the two variables varies strongly depending on the type of communication.

\section{LIMITATIONS AND FURTHER RESEARCH}

Despite the researchers' attempt to explore organizational identification and communication empirically, there were obvious limitations worth noting. First of all, this study reports data that were collected from organizations performing in two different industries. In one industry, task communication was shown to be significantly positively related to organizational identification, while 
career communication was shown to be significantly posititively related to organizational identification in the other industry. This effect is interpreted as being dependent on differences in the functioning of organizations and the perceptions of employees. This kind of differences should be studied in future research with a much larger sample of organizations.

Second, this study used a small sample size from two different industries. Although the sample size of 121 limits the generalizability of the results, the findings give a clear idea about the relationships among organizational identification, communication and commitment. Thus, future research that explores the relationship between the employee levels of identification and organizational communication and commitment across multiple organizations is needed.

Finally, future research should expand upon the conceptual foundation tested in this study and explore other dimensions of organizational phenomenon that may influence organizational identification.

\section{REFERENCES}

Albert, S. and Whetten, D.A. (1985). "Organizational Identity," in L.L.Cummings and B.M. Staw (eds.), Research in Organizational Behavior, 7: 263-296. Greenwich, CT: JAI Press.

Ashforth, B.E. and Mael, F. (1989). "Social Identity Theory and the Organization," Academy of Management Review, 14: 20-39.

Barker, J.R. and Tompkins, P.K. (1994). "Identification in the Self-Managing Organization: Characteristics of Target and Tenure," Human Communication Research, 21: 223-240.

Baron, R.M. and Kenny, D.A. (1986) "The Mediator-Moderator Variable Distinction in Social Psychological Research: Conceptual, Strategic, and Statistical Considerations," Journal of Personality and Social Psychology, 51: 1173-1182.

Blau, G.J. and Boal, K.M. (1987). "Conceptualizing How Job Involvement and Organizational Commitment Affect Turnover and Absenteeism," Academy of Management Review, 12(2): 288-300.

Brewer, M.B. (1981). "Ethnocentrism and Its Role in Interpersonal Trust," in M.B. Brewer and B.E.Collins (eds.), Scientific Inquiry and the Social Sciences: 345-360, New York: Jossey-Bass.

Brewer, M.B. and Kramer, R.M. (1986). "Choice Behavior in Social Dilemmas: Effects of Social Identity, Group Size and Decision Framing," Journal of Personality and Social Psychology, 50: 543549 .

Bullis, C.A. and Tompkins, P.K. (1989). “The Forest Rangers Revisited: A Study of Control Practices and Identification," Communication Monographs, 56: 287-306.

Bullis, C.A. and Bach, B.W. (1989). "Socialization Turning Points: An Examination of Change in Organizational Identification,” Western Journal of Speech Communication, 53: 273-293. 
Caldwell, D.F., Chatman, J.A. and O'Reilly, C.A. (1990). "Building Organizational Commitment: A Multifirm Study," Journal of Occupational Psychology, September: 245-261.

Cheney, G. (1983). "The Rhetoric of Identification and the Study of Organizational Communication," Quarterly Journal of Speech, 69(2): 143-158.

Cheney, G. and Tompkins, P.K. (1987). "Coming to Terms with Organizational Identification and Commitment," Central States Speech Journal, 38: 1-15.

Chreim, S. (2002). "Influencing Organizational Identification during Major Change: A Communication-Based Perspective," Human Relations, 55(9): 1117-1137.

Clampitt, P.G. and Downs, C.W. (1993). "Employee Perceptions of the Relationship between Communication and Productivity: A Field Study," Journal of Business Communication, 30(1): 5-28.

Cohen, J. and Cohen, P. (1983). Applied Multiple Regression/Correlation Analysis for the Behavioral Sciences. $2^{\text {nd }}$ ed. Hillsdale, NJ: Lawrence Erlbaum.

DiSanza, J.R. and Bullis, C. (1999). "Everyone Identifies with Smokey the Bear: Employee Responses to Newsletter Identification Inducement at the US Forest Service," Management Communication Quarterly, 12: 347-399.

Dutton, J.E. and Dukerich, J.M. (1991). "Keeping an Eye on the Mirror: Image and Identity in Organizational Adaptation," Academy of Management Journal, 34: 517-554.

Dutton, J.E., Dukerich, J.M. and Harquail, C.V. (1994). "Organizational Images and Member Identification," Administrative Science Quarterly, 39: 239-263.

Ellemers, N., Kortekaas, P. and Ouwerkerk, J. (1999). "Self-Categorization, Commitment to the Group and Group Self-Esteem as Related but Distinct Aspects of Social Identity," European Journal of Social Psychology, 29: 371-389.

Frank, A. and Brownell, J. (1989). Organizational Communication and Behavior: Communicating to Improve Performance. Orlando, FL: Holt, Rinehart and Winston.

Fontenot, J. and Scott, C.R. (2000). "Correlates of Organizational Identification Moderated by Measurement Scale, Organizational Type and Publication Date: A Meta-Analysis.” Paper presented at the $50^{\text {th }}$ Annual Convention of the ICA, Acapulco, Mexico, June.

Foy, N. (1994). Empowering People at Work. Aldershot, UK: Gower.

Harquail, C.V. (1998). "Organizational Identification and the Whole Person: Integrating Affect, Behavior and Cognition," in D.A. Whetten and P.C. Godfrey (eds.), Identity in Organizations: Building Theory through Conversations: 223-231. Thousand Oaks, CA: Sage. 
Huff, C., Sproull, L. and Kiesler, S. (1989). "Computer Communication and Organizational Commitment: Tracing the Relationship in a City of Government," Journal of Applied Social Psychology, 19: 1371-1391.

Iyer, V.M., Bamber, E.M. and Barefield, R. (1997). "Identification of Accounting Firm Alumni with Their Former Firm: Antecedents and Outcome," Accounting, Organizations and Society (April/May): 315-336.

Katz, D. and Kahn, R.L. (1972). The Social Psychology of Organizations. $2^{\text {nd }}$ ed. New York: Wiley.

Kets de Vries, M.F. (1988). "Origins of Charisma: Ties That Bind the Leader and the Led," in J.A.Conger and R.N. Kanungo (eds.), Charismatic Leadership: 237-252.

Kramer, R.M. and Brewer, M.B. (1984). "Effects of Group Identity on Resource Use in a Simulated Commons Dilemma," Journal of Personality and Social Psychology, 46: 1044-1057.

(1986). "Social Group Identity and the Emergence of Cooperation in Resource Conservation Dilemmas," in H. Wilke, C. Rutte and D.M. Messick (eds.), Experimental Studies of Social Dilemmas: 205-234. Frankfurt, Germany: Peter Long Publishing Company.

Lawler, E.E. (1989). "With HR Help, All Managers can Practice High-Involvement Management," Personnel, April: 26-31.

Lindholm, C. (1988). "Lovers and Leaders: Comparative Models of Romance and Charisma," Social Science Information, 27: 3-45.

Mael, F. and Ashforth, B.E. (1992). "Alumni and Their Alma Mater: A Partial Test of the Reformulated Model of Organizational Identification," Journal of Organizational Behavior, March: 103-123.

----- (1995). "Loyal from Day One: Biodata, Organizational Identification and Turnover among Newcomers," Personnel Psychology, 48: 309-333.

Mael, F.A. and Tetrick, L.E. (1992). "Identifying Organizational Identification," Educational and Psychological Measurement, 52: 813-824.

Meyer, J.P. and Allen, N.J. (1991). "A Three Component Conceptualization of Organizational Commitment," Human Resource Management Review: 161-189.

----- (1997). Commitment in the Workplace: Theory, Research and Application. Thousand Oaks, CA: Sage.

Miller, V.D., Allen, M., Casey, M.K. and Johnson, J.R. (2000). "Reconsidering the Organizational Identification Questionnaire," Management Communication Quarterly, 13: 626-658. 
Myers, S.A. and Kassing, J.W. (1998). "The Relationship between Perceived Supervisory Communication Behaviors and Subordinate Organizational Identification," Communication Research Reports, 15: 71-81.

Nunnally, J. C. (1978). Psychometric Theory. New York: McGraw-Hill.

Penley, L.E. and Hawkins, B. (1985). "Studying Interpersonal Communication in Organizations: A Leadership Application," Academy of Management Journal, 28 (2):309-326.

Pfeffer, J. (1981). "Management as Symbolic Action: The Creation and Maintenance of Organizational Paradigms," in L.L. Cummings and B.M. Staw (eds.), Research in Organizational Behavior, (3): 1-52, Greenwich, CT: JAI Press.

Polzer, J.T. (2002). "Explaining the Varying Effects of Organizational Identification on Cooperation: The Moderating Role of Subgroup Reputations." Working paper.

Postmes, T., Tanis, M. and DeWit, B. (2000). "A Meta-Analysis of Communication and Organizational Commitment: The Coldest Message Elicits the Warmest Feelings.” Unpublished manuscript, University of Amsterdam.

Postmes, T., Tanis, M. and DeWit, B. (2001). "Communication and Commitment in Organizations: A Social Identity Approach,” Group Processes and Intergroup Relations, 4(3): 227-246.

Pratt, M.G. and Rafaeli, A. (1997). "Organizational Dress as a Symbol of Multilayered Social Identities," Academy of Management Journal, 40: 862-898.

Pratt, M.G. (1998). “To Be or Not To Be? Central Questions in Organizational Identification,” in D.A. Whetten and P.C. Godfrey (eds.), Identities in Organizations: Building Theory through Conversations: 171-207. Thousand Oaks: Sage.

Roueche, J.E. and Roueche, S.D. (1996). "Identifying the Strangers: Exploring Part-Time Faculty Integration in American Community Colleges," Community College Review: 23.

Sass, J.S. and Canary, D.J. (1991). "Organizational Commitment and Identification: An Examination of Conceptual and Operational Convergence," Western Journal of Speech Communication, 55: 275293.

Schrodt, P. (2002). "The Relationship between Organizational Identification and Organizational Culture: Employee Perceptions of Culture and Identification in a Retail Sales Organization," Communication Studies, 53(2): 189-202.

Scott, C.R. (2002). “Organizational Member Identification during Communication-Based and Administrative Activities." Paper presented in the Organizational Communication and Information Systems Division at the Annual Conference of the Academy of Management, Denver, CO, August.

Siegel, P.H. and Sisaye, S. (1997). "An Analysis of the Difference between Organization, Identification and Professional Commitment: A Study of Certified Public Accountants," Leadership and Organizational Development Journal, 18: 149-165. 
Smidts, A., Pruyn, A.H. and VanRiel, C.B.M. (2001). "The Impact of Employee Communication and Perceived External Prestige on Organizational Identification," Academy of Management Journal, 49(5): 1051-1062.

Sproull, L. and Kiesler, S. (1986). "Reducing Social Context Cues: Electronic Mail in Organizational Communication," Management Science, 32: 1492-1512.

----- (1991). Connections: New Ways of Working in the Networked Organization. Cambridge, MA: MIT Press.

Tajfel, H. (1972). "Social Categorization," in S. Moscovici (ed.), Introduction a la Psychologie Sociale. Paris: Larousse.

----- (1978). “The Achievement of Group Differentiation,” in H. Tajfel (ed.), Differentiation between Social Groups: Studies in the Social Psychology of Intergroup Relations: 77-98. London: Academic Press.

----- (1981). Human Groups and Social Categories: Studies in Social Psychology. New York: Cambridge University Press.

Turner, J.C. (1987). Rediscovering the Social Group: A Self-Categorization Theory. New York: Basil Blackwell.

Van Knippenberg, D. and Sleebos, E. (2000). "Further Explorations of the Organizational Identification Concept: Identification versus Commitment." Manuscript submitted for publication.

Van Knippenberg, D. and Van Schie, E.C.M. (2000). "Foci and Correlates of Organizational Identification," Journal of Occupational and Organizational Psychology, 73: 137-148.

Wiesenfeld, B.M., Raghuram, S., and Garud, R. (1999). "Communication Patterns as Determinants of Organizational Identification in a Virtual Organization," Organization Science.

Zack, M.H. (1993). "Interactivity and Communication Made Choice in Ongoing Management Groups," Information Systems Research, 4(3): 207-239. 


\section{APPENDIX A}

Career Communication Scale Items (Penley and Hawkins, 1985)

1. My supervisor encourages me to develop my career.

2. My supervisor discusses with me how to get additional training.

3. My supervisor gives me advice on developing my career.

4. My supervisor makes me aware of the demands of future jobs in my career path.

5. My supervisor gives me information on training opportunities.

Task Communication Scale Items (Penley and Hawkins, 1985)

1. My supervisor clearly explains policy changes.

2. My supervisor lets us know about changes, which are coming up.

3. My supervisor lets me know what work needs to be done.

4. My supervisor discusses with me how to handle problems in my work.

Organizational Identification Scale Items (Mael and Ashforth, 1992)

1. When I talk about my organization, I usually say 'we' rather than 'they'.

2. My organization's successes are my successes.

3. I am very interested in what others think about my organization.

4. When someone praises my organization, it feels like a personal compliment.

5. If a story in the media criticized my organization, I would feel embarrassed.

\section{Affective Commitment Scale Items (Meyer and Allen, 1991)}

1. I do not feel like part of a family at my organization. (R)

2. I feel emotionally attached to my organization.

3. Working at my organization has a great deal of personal meaning for me.

4. I feel a strong sense of belonging to my organization.

5. I would be happy to work at my organization until I retire.

6. I really feel that any problems faced by my organization are also my problems.

7. I enjoy discussing my organization with people outside of it. 